\title{
The Travesty Dancer in Nineteenth-Century Ballet
}

\author{
Lynn Garafola
}

More than any other era in the history of ballet, the nineteenth century belongs to the ballerina. She haunts its lithographs and paintings, an ethereal creature touched with the charm of another age. Yet even when she turned into the fast, leggy ballerina of modern times, her ideology survived. If today the art of ballet celebrates the danseur nearly as often as the danseuse, it has yet to rid its aesthetic of yesterday's cult of the eternal feminine. Like her nineteenth-century forbear, today's ballerina, an icon of teen youth, athleticism, and anorexic vulnerability, incarnates a feminine ideal defined overwhelmingly by men.

The nineteenth century did indeed create the mystique of the ballerina. But it also gave birth to one of the more curious phenomena of ballet history. Beginning with romanticism, a twenty-year golden age stretching from the July Revolution to about 1850, the danseuse en travest $i$ usurped the position of the male danseur in the corps de ballet and as a partner to the ballerina. Stepping into roles previously filled by men, women now impersonated the sailor boys, hussars, and toreadors who made up "masculine" contingents of the corps de ballet, even as they displaced real men as romantic leads. Until well into the twentieth century, the female dancer who donned the mufti of a cavalier was a commonplace of European ballet.

In real life, donning men's clothing meant assuming the power and prerogatives that went with male identity. Cross-dressing on the stage, however, had quite different implications. Coming into vogue at a time of major social, economic, and aesthetic changes, it reflected the shift of ballet from a courtly, aristocratic art to an entertainment geared to the marketplace and the tastes of a new bourgeois public.

Thus the danseur did not vanish in Copenhagen, where August Bournonville guided the destiny of the Royal Theater for nearly five decades, or at the Maryinsky Theater in St. Petersburg, where Marius Petipa ruled the Imperial Ballet for a similar tenure. On these courtly stages the male remained, even if eclipsed by the ballerina.

Where he fought a losing battle was in those metropolitan centers that stood at the forefront of the new aesthetic-Paris and London. At the prestigious cradles of ballet romanticism in these cities, the Paris Opéra and King's Theatre, he was edged gradually but firmly from the limelight by a transformation in the social relations of ballet as thoroughgoing as the revolution taking place in its art.
Unlike the theaters of the periphery, where government control of arts organization remained intact, those of the European core operated, or began to operate, as private enterprises. ${ }^{1}$ Entrepreneurs stood at the helm, with subscribers paying all or a substantial share of the costs-even at the Paris Opéra which continued to receive partial subsidy from the government after losing its royal license in 1830. This change in the economic structure of ballet placed the audience-particularly the key group of monied subscribers-in a new and powerful position. It led to a new kind of star system, one based on drawing power rather than rank, while eliminating, for purposes of economy, the pensions and other benefits traditionally accruing to artists in government employ. The disappearance of the male dancer coincided with the triumph of romanticism and marketplace economics.

The ban on male talent was not, strictly speaking, absolute. Even in the second half of the century in England and on the Continent, men continued to appear in character roles such as Dr. Coppélius, the doddering, lovestruck Pygmalion of Coppélia, parts that demanded of dancers skill as actors and mimes and could be performed by those long past their prime. Men on the ballet stage were fine, it seemed, so long as they left its youthful, beardless heroes to the ladies and so long as they were elderly and, presumably, unattractive.

Initially, then, the "travesty" problem defines itself as one of roles, specifically, that of the romantic hero, who incarnated, along with his ballerina counterpart, the idealized poetic of nineteenth century ballet. In the new era opened by the July Revolution, this aesthetic and the styles of masculine dancing associated with its expression became gradually "feminized." Scorned by audiences as unmanly, they became the property of the danseuse en travesti, that curious androgyne who invoked both the high poetic and the bordello underside of romantic and post-romantic ballet.

Although travesty roles were not unknown before 1789, they were rare, especially in the so-called genre noble, the most elevated of the eighteenth century's three balletic styles. ${ }^{2}$ Indeed, its most distinguished exponents were men, dancers like Auguste Vestris, who brought a supreme elegance and beauty of person to the stage and majestic perfection to the adagios regarded as the touchstone of their art. No one embodied more than the danseur noble the courtly origins of ballet, its aristocratic manner, and the masculinity of a refined, leisured society.

Already by 1820 , the danseur noble appealed to a very 


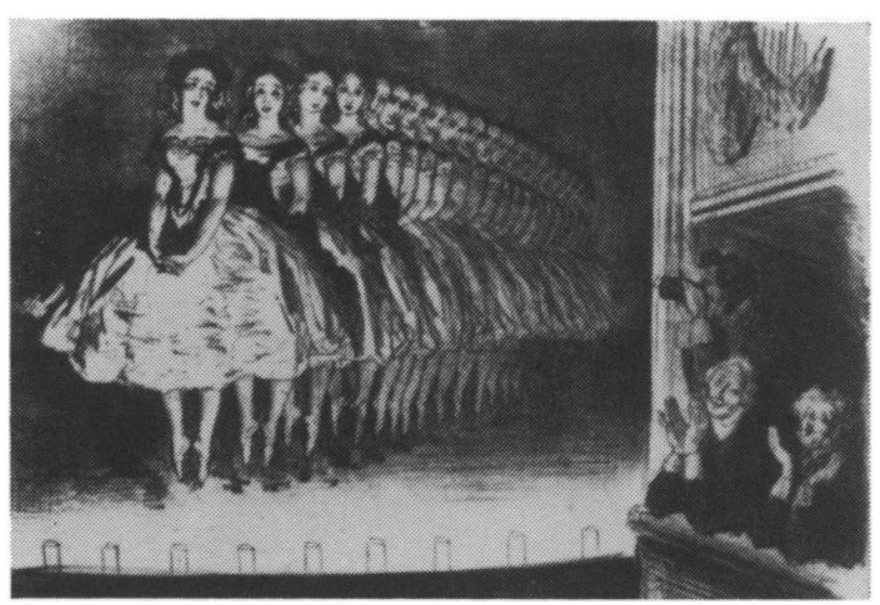

"Rats d'opéra," Paris, 1854. "Rat" was the slang expression for the ballet girl. Note the rapturous expression on the faces of the elderly gentlemen in the stage box and the man with the opera glasses. Note, too, the youth of the dancers and their eyes, trained on their admirers.

limited public-connoisseurs and men of refined tastes. To the increasing numbers from the middle classes who began to frequent the Paris Opéra in the later years of the Restoration, his measured dignity and old-fashioned dress betrayed, like the genre noble itself, the aristocratic manner and frippery of the Ancien Régime.

In the changing social climate of the 1820 s, then, a new kind of gendering was underway. The men about town who formed the backbone of the growing bourgeois public saw little to admire in the stately refinements of the danseur noble. Their taste instead, ran to the energized virtuosity of a danseur de demi-caractère like Antoine Paul whose acrobatic leaps and multiple spins offered an analogue of their own active, helter-skelter lives. The high poetic of ballet, the loftiness of feeling embodied by the danseur noble, came to be seen as not merely obsolete, but also unmanly. With the triumph of romanticism and the new, ethereal style of Marie Taglioni in the early 1830s, poetry, expressiveness, and grace became the exclusive domain of the ballerina. At the same time, advances in technique, especially the refining of pointe work, gave her a second victory over the male: she now added to her arsenal of tricks the virtuosity of the danseur de demi-caractère. By 1840, a critic could write, "If male dancing no longer charms and attracts today, it is because here is no Sylphide, no magic-winged fairy capable of performing such a miracle and doing something that is endurable in a male dancer. ${ }^{\prime 3}$

In appropriating the aesthetic idealism and virtuoso technique associated with the older genres of male dancing, the ballerina unmanned the danseur, reducing him to comic character and occasional "lifter." But her gain had another effect, more lasting even than the banishment of the male from the dance stage. Beginning with romanticism and continuing throughout the nineteenth century, femininity itself became the ideology of ballet, indeed, the very definition of the art. Ideology, however, turned out to be a false friend. Even as nineteenth-century ballet exalted the feminine, setting it on a pedestal to be worshipped, its social reality debased the danseuse as a worker, a woman, and an artist.

From the romantic era with its triumphant bourgeoisie and market ethos came the dual stigma of working-class origins and sexual impropriety that branded the woman dancer well into the twentieth century. The great ballerinas continued, by and large, to emerge from the theatrical clans that had survived from the eighteenth century, a kind of caste that trained, promoted, and

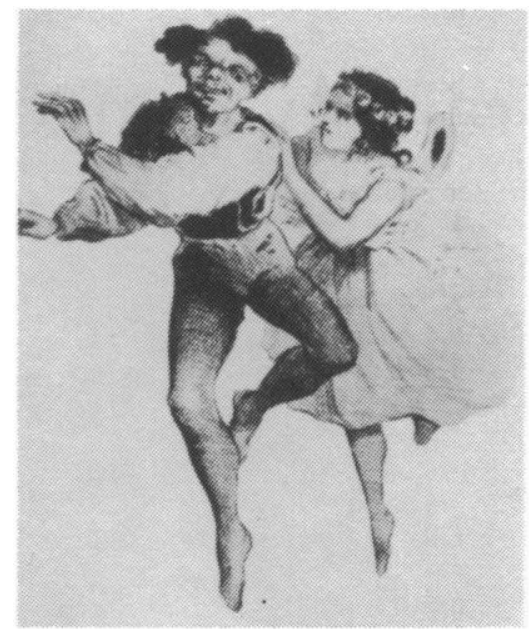

A caricature of the period that leaves little doubt of the growing contempt for the male dancer.

protected its daughters. (Taglioni, for instance, arrived in Paris in 1827 with a brother to partner her and a father who coached her, choreographed for her, and acted as her personal manager.) The rest, however, belonged to the urban slums. "Most of the dancers," wrote Albéric Second in 1844, "first saw the light of day in a concierge's lodge. ${ }^{\prime 4}$ Bournonville summed up the lot of the majority succinctly-humble origins, little education, and wretched salaries. ${ }^{5}$

Poverty, naturally, invites sexual exploitation, especially in a profession of flexible morals. (Liaisons sweeten almost every ballerina biography. $\left.\right|^{6}$ In the $1830 \mathrm{~s}$, however, the backstage of the Paris Opera became a privileged venue of sexual assignation, officially countenanced and abetted. Eliminating older forms of "caste" separation, the theater's enterprising management dangled before the elect of its paying public a commodity of indisputable rarity and cachet-its female corps of dancers.

Imagine for a moment the inside of the old Paris Opéra. Descending tier by tier from the gods, we move up the social scale, until, finally, we stand at the golden horseshoe of wealth, privilege, and power where, in boxes three-deep on either side of the proscenium, sit the pleasure-minded sportsmen of the Jockey Club.

As the Opéra's most influential abonnés, the occupants of these loges infernales-all male, of course-enjoyed certain privileges: the run of the coulisses, for example, and entry to the Foyer de la Danse, a large room lined with barres and mirrors just behind the stage. Before 1830 , lackeys in royal livery had warded prying eyes from this warm-up studio. When the new regime turned the Opéra over to private management, the Foyer de la Danse acquired a different function. ${ }^{7}$ No longer off limits to men of wealth and fashion, before and after performances it became an exclusive maison close, with madams in the shape of mothers arranging terms. Nowhere was the clash, evoked time and again in lithographs and paintings, between the idealized femininity of balletic ideology and the reality of female exploitation so striking as in the Opéra's backstage corridors.

The commerce in dancers' bodies was not peculiar to Paris. In London, remarked Bournonville, it lacked even the pretension of gallantry that accompanied such exchanges across the Channel. To be sure, some dancers did eventually marry their "protectors." Many more bore children out of wedlock, sending them in secrecy to distant relations or country families to be reared. Nor did 


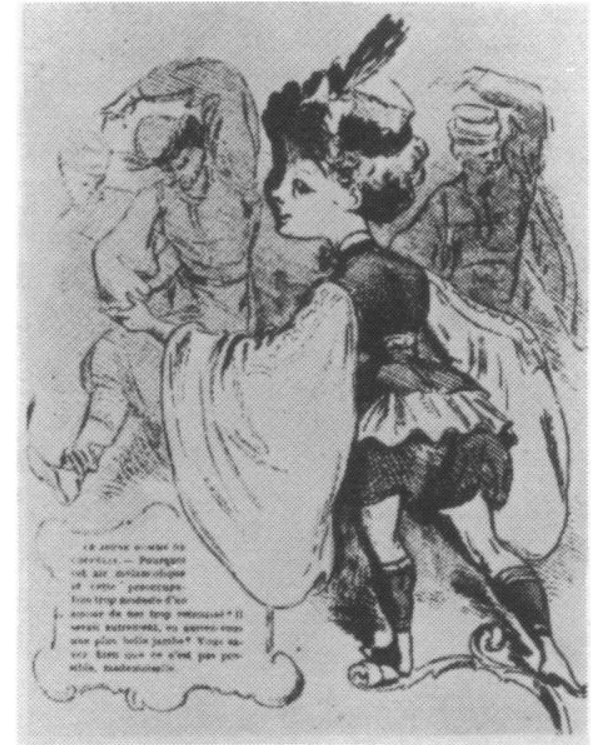

Caricature by Marcelin of Eugénie Fiocre as Frantz in Coppélia.

marriages between dancers fare well in this atmosphere of libertinage: one thinks of the choreographer Arthur Saint-Léon, Fanny Cerrito's on and off-stage partner, who, jealous of the gifts showered on his beautiful and brilliant wife (which he could neither duplicate nor reciprocate), left the field of battle to his competitors. ${ }^{8}$ The association of ballet and prostitution was so pervasive that Ivor Guest in his history of ballet under the Second Empire makes a special point of noting the Opéra's good girls-model wives, midnight poets, authors of books of religious reflections. But such cases were only exceptions. For pleasure-loving Paris, dancers were the cream of the demi-monde.

Aesthetics today stresses the dancer's symbolic function: it views physical prcsence as the form of dance itself. In the nineteenth century, however, the danseuse was first and foremost a woman. Like her audience, she saw the task of ballet as one of charming the sensibility, not elevating the mind. Tilting her face to the loges infernales, flashing the brilliants of her latest protector, making up with coquetry the shortcomings of technique, she presented herself as a physical synecdoche, a dancer without the dance. For the nineteenth-century public, ballet offered a staged replay of the class and bordello politics that ruled the theater corridors.

Conventional wisdom has it that there were two sorts of romantic ballerinas: "Christians" who evoked romanticism's spiritual yearnings and supernal kingdoms, and "pagans" who impersonated its obsession with exotic, carnal, and material themes. ${ }^{9}$ But this paradigm, invented by Théophile Gautier to describe the contrasting styles of Marie Taglioni and Fanny Elssler, is at best misleading. For no matter how patly the virgin/whore scheme seems to fit the ideology of romanticism, it ignores both the dancer's totemic reality-her position within the social order of ballet-and that troubling third who articulated the common ground of the period's balletic avatars of Eve. As an emblem of wanton sexuality, feminized masculinity, and amazon unviolability, the danseuse en travesti symbolized in her complex persona the many shades of lust projected by the audience on the nineteenth-century dancer.

Unlike the older genre distinctions based on body type, movement, and style, romanticism's female tryptich aligned balletic image with a hierarchy of class and sexual

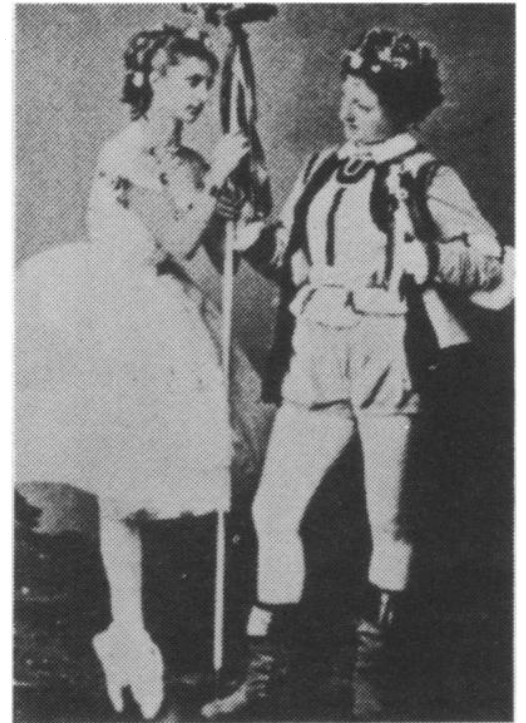

Angelina Fioretti and Blanche Montaubry in the divertissement of Hamlet, an opera by Amboise Thomas (1868), choreographed by Lucien Petipa.

practice. If Taglioni's "aerial, virginal grace" evoked romanticism's quest for the ideal, it also summoned to the stage the marriageable démoiselle, chaste, demure, and genteel. So, too, Elssler's "swooning, voluptuous arms," like her satins, laces, and gems, linked the concept of materialism with a particular material reality-the enticing, high-priced pleasures of a grande horizontale.

The travesty dancer practised none of these symbolic feminine concealments. As shipboys and sailors, hussars and toreadors, the proletarians of the Opéra's corps de ballet donned breeches and skin-tight trousers that displayed to advantage the shapely legs, slim corseted waists, and rounded hips, thighs, and buttocks of the era's ideal figure. Like the prostitutes in fancy dress in Manet's "Ball at the Opera," the danseuse en travesti brazenly advertised her sexuality. She was the hussy of the boulevards on theatrical parade.

The masquerade of transvestism fooled no one, nor was it meant to. The danseuse en travesti was always a woman, and a highly desirable one (a splendid figure was one of the role's prerequisites). She may have aped the steps and motions of the male performer, but she never impersonated his nature. What audiences wanted was a masculine image deprived of maleness, an idealized adolescent, a beardless she-man. Gautier, in particular, was repelled by the rugged physicality of the danseur, that "species of monstrosity," as he called him..$^{10}$ "Nothing," he wrote, "is more distasteful than a man who shows his red neck, his big muscular arms, his legs with the calves of a parish beadle, and all his strong massive frame shaken by leaps and pirouettes. ${ }^{\prime \prime 1}$

His critical colleague, Jules Janin, shared Gautier's prejudices: even the greatest of danseurs paled against the delicate figure, shapely leg, and facial beauty of the travesty dancer. Janin, however, added another element to Gautier's list of characteristics unbecoming in a male dancer - power. No real man, that is, no upstanding member of the new bourgeois order, could impersonate the poetic idealism of the ballet hero without ungendering himself, without, in short, becoming a woman in male drag. Janin's remarks, published in the Journal des Débats, are worth quoting at length:

Speak to us of a pretty dancing girl who displays the grace of her figure, who reveals so fleetingly all the 

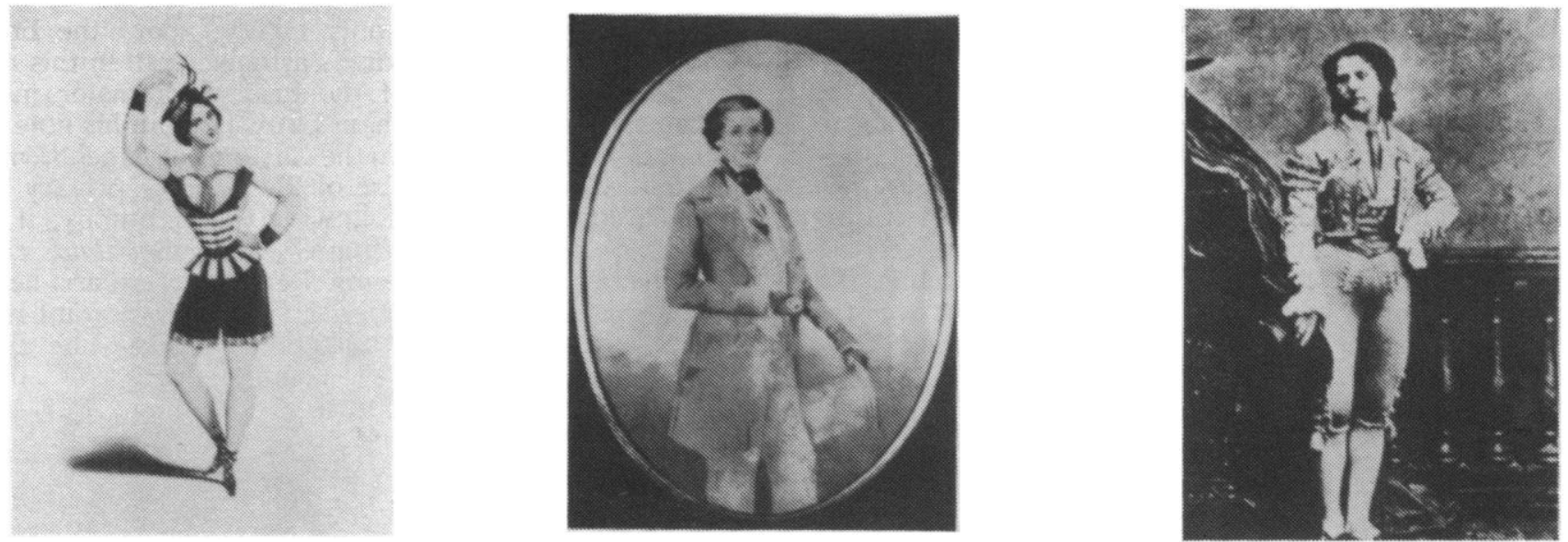

L to R: Zina Richard in Trilby (1846); Fanny Elssler as Georges in Le Muet d'Ingouville (1851); Louise Marquet in Graziosa (1861).

treasures of her beauty. Thank God, I understand that perfectly, I know what this lovely creature wishes us, and I would willingly follow her wherever she wishes in the sweet land of love. But a man, as ugly as you and I, a wretched fellow who leaps about without knowing why, a creature specially made to carry a musket and a sword and to wear a uniform. That this fellow should dance as a woman does impossible! That this bewhiskered individual who is a pillar of the community, an elector, a municipal councillor, a man whose business it is to make and ... unmake laws, should come before us in a tunic of sky-blue satin, his head covered with a hat with a waving plume amorously caressing his cheek, a frightful danseuse of the male sex ... this was surely impossible and intolerable, and we have done well to remove such ... artists from our pleasures. Today, thanks to this revolution we have effected, woman is the queen of ballet ... no longer forced to cut off half her silk petticoat to dress her partner in it. Today the dancing man is no longer tolerated except as a useful accessory. ${ }^{12}$

As the concept of masculinity aligned itself with productivity, the effeminate sterility of the danseur became unacceptable to ballet's large male public.

But in defining power as male, Janin implicitly defined powerlessness as female. In photographs of the danseuse en travesti posed with her female counterpart, the modern eye notes a curtailment of scale, a reduction not only in the height and girth of the masculine figure, but in the physical contrast of the imaged sexes. What is missing, above all, is the suggestion of dominance, that intimation of power that even the most self-effacing danseur communicates to his audience. In appropriating the male role, the travesty dancer stripped that role of power.

In eliminating the danseur, ballet turned out the remaining in-house obstacle to sexual license. With the decline of the clan, only his lust, that last bastion of power, stood between the danseuse and the scheme so artfully contrived by the entrepreneurs of ballet for the millionaire libertines of the audience. For what was the Opéra if not their private seraglio? Thanks to the travesty dancer, no male now could destroy the peace of their private harem or their enjoyment of performance as foreplay to possession.

In appearance, the feminine androgyne laid claim to another erotic nexus. Tall, imposing, and majestic, she added to the charm of wantonness the challenge of the amazon, that untamed Diana who so fascinated the nineteenth-century imagination. In Gautier's description of Eugénie Fiocre as Cupid in Néméa, note the sapphic allusions.

Certainly Love was never personified in a more graceful, or more charming body. Mlle. Fiocre has managed to compound the perfection both of the young girl and of the youth, and to make of them a sexless beauty, which is beauty itself. She might have been hewn from a block of Paros marble by a Greek sculptor, and animated by a miracle such as that of Galatea. To the purity of marble, she adds the suppleness of life. Her movements are developed and balanced in a sovereign harmony... What admirable legs! Diana the huntress would envy them! What an easy, proud and tranquil grace! What modest, measured gestures!...So correct, rhythmical and noble is her miming that, like that of the mimes of old, it might be accompanied by two unseen fluteplayers. If Psyche saw this Cupid she might forget the original. ${ }^{13}$

Fiocre, an exceptionally beautiful woman who created the role of Frantz in Coppelia, was one of the most famous travesty heroes of the $1860 \mathrm{~s}$ and 1870 s. Like a number of Opéra dancers, she shared the boards with a sister, whose shapely limbs commanded nearly as much admiration as her sibling's. By far, the most fascinating sister pair of the century were the Elsslers-Fanny, the romantic temptress with the body of a "hermaphrodite of antiquity,"14 and Thérèse, her partner and faithful cavalier. For over ten years they danced together, lived together, and traveled together. On stage they communicated a veiled eroticism, while offstage their relationship suggested a feminized relic of the older clan system.

A giraffe of a dancer at $5{ }^{\prime} 6$ ", the "majestic" Thérèse served her diminutive sister in the multiple roles reserved in an older era for the ballerina's next of kin. She handled all of Fanny's business affairs, decided where and what she should dance, and staged, without credit, many of the ballets and numbers in which they appeared. As a woman, however, Thérèse lacked the clan's patriarchal authority, while as a dancer, she would always be without the wealth and power of the "protectors" who increasingly materialized behind the scenes- promoting favorites, dispensing funds as well as maintaining dancers and their impoverished families. Indeed, one such protector, the self-styled Marquis de La Valette, who became 
Fanny's lover in 1837, eventually destroyed the sororial ménage: his scorn for the ex-dancer who shared her bed forced Thérèse to leave.

One expects that the likes of the Marquis de La Valette relished the sight of his Elssler girls charming confreres of the loges infernales. But one also suspects that the travesty pas de deux was not so completely unsexed as the household he ruled. Certainly, it had been neutered by the substitution of a woman for the man, but that hardly means it was devoid of erotic content. Might not audiences have perceived in the choreographic play of female bodies, something other than two women competing to whet the jaded appetites of libertines? Consider Gautier's account of a duet performed by the two Elsslers:

The pas executed by Mlle. T. Elssler and her sister is charmingly arranged; there is one figure in particular where the two sisters run from the back-cloth hand in hand, throwing forward their legs at the same time, which surpasses everything that can be imagined in the way of homogeneity, accuracy, and precision. One might almost be said to be the reflection of the other, and that each comes forward with a mirror held beside her, which follows her and repeats all her movements.

Nothing is more soothing and more harmonious to the gaze than this dance at once so refined and so precise.

Fanny, to whom Theresa has given as ever the more important part, displayed a child-like grace, an artless agility, and an adorable roguishness; her Creole costume made her look ravishing, or rather she made the costume look ravishing. ${ }^{15}$

Thérèse had choreographed La Volière ("The Aviary" in English), which like her other ballets and dances made no use of men: she cast herself in the masculine role. Yet despite the differences in their attire, what struck Gautier was the oneness of the pair: he saw them as refracted images of a single self, perfect and complete. In evoking an Arcadia of perpetual adolescence untroubled and untouched by man, the travesty duet hinted at an ideal attainable only in the realms of art and the imagination-not the real world of stockbrokers and municipal councillors.

But dancing by its very nature is a physical as much as symbolic activity. In the formalized mating game of the travesty pas de deux, two women touching and moving in harmony conveyed an eroticism perhaps even more compelling than their individual physical charms. The fantasy of females at play for the male eye is a staple of erotic literature, a kind of travesty performance enacted in the privacy of the imagination. Ballet's travesty pas de deux gave public form to this private fantasy, whetting audience desire, while keeping safely within the bounds of decorum. For ultimately, sapphic love interfered with the smooth functioning of the seraglio as much as the obstreperous male. In the case of the Elsslers, where Therèse seems to have animated her choreography with something akin to personal feeling, the incest taboo coded as sisterly devotion what might otherwise have been construed as love. And one cannot help thinking that the buxom travesty heroes of the Second Empire and subsequent decades flaunted an outrageous femininity to ward off the sapphism immanent in their roles. In so doing, however, ballet robbed the danseuse of erotic mystery.

Today, thanks to the example of the Ballets Trocadero, we are apt to think that travesty in dance inherently offers a critique of sexual role playing. But the travesty dancers of nineteenth-century ballet offered no medi-

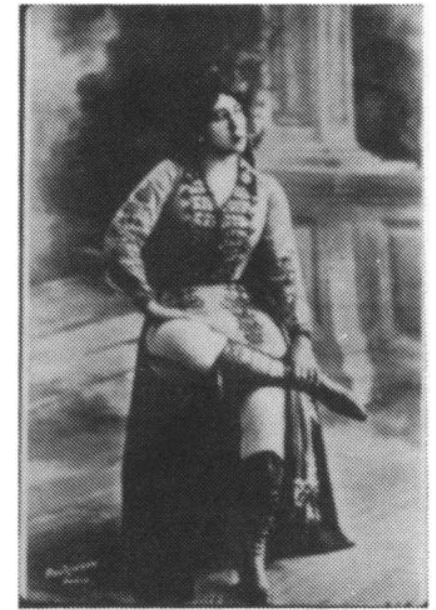

"La Belle" Otéro

tation on the usages of gender, no critical perspective on the sexual politics that ruled their lives, no revelation of the ways masculine and feminine were imaged on the ballet stage. What they exemplified was the triumph of bordello politics ideologized as the feminine mystique-a politics and an ideology imposed by men who remained in full control of ballet throughout the century as teachers, critics, choreographers, spectators, and artistic directors.

The advent in 1909 of Diaghilev's Ballets Russes with its dynamic new aesthetic shattered the travesty paradigm. Seeing real men on the stage in choreography that exploited the strength, athleticism, and scale of the male body simply electrified audiences, causing them to look anew at the travesty dancer. But the audience itself had changed dramatically. The new following for ballet came from the highly sophisticated milieu of le tout Paris. The great connoisseurs, collectors, musical patrons, and salonnières of the French capital-many of whom were women-replaced the sportsmen and roués of the loges infernales. At the same time a new androgynous thematic and iconography, particularly evident in works created for Nijinsky where images of sexual heterodoxy transgressed rigid categories of masculinity and femininity, regendered the ideology of ballet, ending the reign of the feminine mystique. The era of the danseuse en travesti had come to an end.

\section{NOTES}

1. For the dramatic changes in the organization of the Paris Opéra after the Revolution of 1830 , see Ivor Guest, The Romantic Ballet in Paris, forewords Ninette de Valois and Lillian Moore, 2nd ed. rev. (London: Dance Books, 1980), pp. 22-25. In England, nineteenth-century ballet appeared exclusively in a commercial setting. John Ebers, a former ticket agent, assumed the management of the King's Theatre in $\mathbf{1 8 2 0}$ an association that ended in bankruptcy in 1827. He was succeeded in 1828 by Pierre Laporte, who, with the exception of the 1832 season, controlled the opera house until his death in 1841, whereupon Benjamin Lumley, in charge of finances since 1836, assumed the theater's management. In the hands of this solicitor/impresario, Her Majesty's (as the King's Theatre had been renamed) entered upon an era of glory. In the 1830s and 1840s, under the management of Alfred Bunn, the Theatre Royal, Drury Lane became another important venue for ballet. During the latter part of the nineteenth century up to the eve of World War I, ballet lived on in the music-halls, above all, the Empire and Alhambra. Ivor Guest, The Romantic Ballet in England: Its Development, Fulfilment and Decline (London: Phoenix House, 1954), pp. 33, 46, 8387, 128-131; The Empire Ballet (London: Society for Theatre Research, 1962): "The Alhambra Ballet," Dance Perspectives, Autumn 1959. 
In France, it should be noted, the commercial boulevard stage was the breeding ground for theatrical romanticism. Long before the Paris Opéra's Robert le Diable, usually considered the official point of departure for romantic ballet, spectacular techniques and supernatural effects were commonplace in the melodramas and vaudevilles of the popular theaters. Ballet was an important component of these spectacles. Indeed, it was at theaters like the Theâtre de la Porte-Saint-Martin, which maintained a resident troupe and regularly presented new ballets and revivals. that the aerial style of dancing associated with romanticism began to crystallize early in the 1820 s. Among the talents associated with the flowering of romantic ballet at the Paris Opéra who gained early experience on the boulevard stage were Jean Coralli, who produced several ballets at the Théatre de la Gaité. Guest, The Romantic Ballet in Paris, pp. 4-5, 13-14, 16, Appendix D, pp. 272-274; Marian Hannah Winter, The Pre-Romantic Ballet (London: Pitman, 1974), pp. 178-179, 193-197.

2. Some instances of gender swapping prior to the nineteenth century are Marie Sallé's appearance as Amour in Handel's Alcina (which Salle choreographed herself) and the three graces impersonated by men in Plathée, Jean-Philippe Rameau's spoof of his own operatic style. The lover in disguise à la Shakespeare's Twelfth Night was a popular conceit that called for cross-dressing. I am grateful to Catherine Turocy for this information. For the response of the London audience to Salle's performance, see Parmenia Migel, The Ballerinas From the Court of Louis XIV to Pavlova (1972; rpt. New York: Da Capo, 1980), p. 25.

3. Le Constitutionnel, quoted in Guest, The Romantic Ballet in Paris, p. 1.

4. Les Petits Mystères de l'Opéra, quoted in Guest, The Romantic Ballet in Paris, p. 25.

5. August Bournonville, My Theatre Life, trans. Patricia N. McAndrew (Middletown: Wesleyan Univ. Press, 1979), p. 52.

6. Fanny Cerrito's liaison with the Marqués de Bedmar, Carlotta Grisi's with Prince Radziwill, Fanny Elssler's with the Marquis de La Valette, Pauline Duvernay's with (among others) Valette and Lyne Stephens, and Elisa Scheffer's with the Earl of Pembroke are a few of the romances that dot the ballet chronicle of the 1830s, 1840s, and 1850 s.

7. For the changes introduced by Dr. Louis Véron at the Paris Opéra after the Revolution of 1830, see Guest, The Romantic Ballet in Paris, $\mathrm{p}$. 28. Under Ebers, the Green Room built at the Kings's Theatre performed a similar function as the Foyer de la Danse, while at Drury Lane, Bunn allowed the more influential patrons the run of the coulisses. Procuresses of "of the worst type" circulated backstage at Drury Lane, among them the blackmailing beauty specialist known as Madame Rachel. Guest, The Romantic Ballet in England, pp. 36-37, 113.

8. Migel, The Ballerinas, p. 218. Married in 1845 (to the chagrin of Cerrito's parents who had hoped for a son-in-law with a fortune or at least a title), the couple broke up in 1851. Shortly thereafter, her liaison with the Marqués de Bedar became public knowledge. When rumors began to circulate in 1844 about Cerrito's impending marriage to SaintLéon, the ballerina's London admirers, headed by Lord MacDonald, created a public disturbance when Saint-Léon appeared onstage. During one performance, the dancer stopped before their box and with a "sarcastic grin" and an "indescribable gesture" hissed menacingly at Lord Macdonald. The word cochon was heard to leave Saint-Léon's mouth, a gross impertinence coming from a dancer. Saint-Léon's written apology appeared in the Times a few days later. Ivor Guest, Fanny Cerrito: The Life of a Romantic Ballerina, 2nd ed. rev. (London: Dance Books, 1974), p. 85.

9. "Fanny Elssler in 'La Tempete'," in The Romantic Ballet as Seen by Theophile Gautier, trans. Cyril W. Beaumont (London, 1932; rpt. New York: Arno Press, 1980), p. 16.

10. "Perrot and Carlotta Grisi in 'Le Zingaro'," ibid., p. 44.

11. "The Elsslers in 'La Volière'," ibid., p. 24.

12. 2 March 1840, quoted in Guest, Romantic Ballet, p. 21.

13. Quoted in Ivor Guest, The Ballet of the Second Empire (Middletown: Wesleyan Univ. Press, 1974), p. 200.

14. "Fanny Elssler," in Gautier, p. 22.

15. "The Elsslers in 'La Volière'," p. 24. 